\title{
Florida 2003 Short, Mid, and Full Season Corn Variety Tests for Silage and Grain ${ }^{1}$
}

\section{D.L. Wright, J.J. Marois, P.J. Wiatrak and B. Kidd ${ }^{2}$}

The objective of the corn variety trials was to compare various corn varieties for silage and grain yields grown under North Florida weather conditions. The studies were conduced on a Dothan sandy loam (fine loamy siliceous, thermic Plinthic Kandiudult) at the North Florida Research and Education Center (NFREC) / University of Florida, Quincy, Florida in 2003.

The experimental area planted in rye was broadcast sprayed with Banvel @ 0.5 pt/A + Roundup WeatherMax @ 32 oz/A on 11 March, and rows were ripped with the Brown Ro-till implement on 25 March. On 1 and 2 April, corn was planted strip-till with a Cone planter in $23 \mathrm{ft}$ long plots and 3 $\mathrm{ft}$ row spacing, fertilized with 3-9-18 $\left(\mathrm{N}-\mathrm{P}_{2} \mathrm{O}_{5}-\mathrm{K}_{2} \mathrm{O}\right)$ fertilizer@600 lbs/A (2-3 inches beside the planted corn rows), and broadcast sprayed with Roundup WeatherMax@1 pt/A. All studies were broadcast sprayed with Dual II Magnum @ 1.5 pt/A + Aatrex @ 1 qt/A on 11 April and Permit @ 1.33 oz/A + Induce @ 1.5 qt/A on 24 April. On 28 April, corn was side-dressed with ammonium nitrate (34-0-0) @ 450 $\mathrm{lbs} / \mathrm{A}$. All studies were irrigated at 0.3 inch on 7
April, 0.6 inch on 15 April, 0.5 inch on 1 and 2 May, 0.6 inch on 9 May, and 0.5 inch on 13 May. A Hesston silage chopper was used to cut 2 rows of corn x $23 \mathrm{ft}$ for silage on 15 July (Short and Mid Season Variety Trial for Silage) and on 28 July (Full Season Variety Trial for Silage) at the $1 / 2$ kernel milk-line stage. Silage yields were calculated to $35 \%$ dry matter (DM). Corn was harvested for grain with a corn supersheller on 11 and 14 August (Short Season Variety Trial for grain) and on 14-18 August (Mid and Full Season Variety Trial for grain). Corn grain yields were adjusted to $15.5 \%$ moisture.

Tables 1 and 2 show silage yields for the Short and Mid, and Full Season Corn Variety Trials, and Tables 3 and 4 show grain yields for the Short and Mid and Full Season Corn Variety Trails.

\section{Key management Considerations for Corn Production:}

\section{Variety selection-Varieties should be} compared over years and location for consistency in yield and quality.

1. This document is SS-AGR-160, one of a series of the Agronomy Department, Florida Cooperative Extension Service, Institute of Food and Agricultural Sciences, University of Florida. Published February 2004. Visit the EDIS Web Site at http://edis.ifas.ufl.edu.

2. D.L. Wright, Professor, Agronomy Department, J.J. Marois, Professor, Plant Pathology Department, P.J. Wiatrak, Assistant in Agronomy, B. Kidd, Biological Scientist; North Florida Research and Education Center-Quincy, FL; Florida Cooperative Extension Service, Institute of Food and Agricultural Sciences, University of Florida, Gainesville, FL 32611.

The use of trade names in this publication is solely for the purpose of providing specific information. UF/IFAS does not guarantee or warranty the products named, and references to them in this publication does not signify our approval to the exclusion of other products of suitable composition.

The Institute of Food and Agricultural Sciences (IFAS) is an Equal Opportunity Institution authorized to provide research, educational information and other services only to individuals and institutions that function with non-discrimination with respect to race, creed, color, religion, age, disability, sex, sexual orientation, marital status, national origin, political opinions or affiliations. U.S. Department of Agriculture, Cooperative Extension Service, University of Florida, IFAS, Florida A. \& M. University Cooperative Extension Program, and Boards of County Commissioners Cooperating. Larry Arrington, Dean 
2. Fertilizer-Starter fertilizer should be applied 2 " X 2" or as a surface dribble and not sprayed over the row in a wide band. Nitrogen should be applied on the surface an inch away from the row for each 10 lbs/A N used. Starter N mixtures containing 50\% solution of $\mathrm{N}+\mathrm{S}$ and 50\% 10-34-0 makes a good starter for corn.

3. Conservation tillage-Strip-till planting decreases erosion, increases soil organic matter, soil moisture, and improves soil texture and may result in increased yields. Strip till rigs should have in-row rippers to break through the compaction layer to improve root growth and yield under stress conditions.

4. Cover crops - Cover crops should be killed 3 to 4 weeks prior to planting to reduce insect problems and potential moisture deficits.

5. Planting date-Plantings made from mid-February to mid-April are most suitable for corn in Florida to avoid severe insect and disease problems.

6. Plant population-Irrigated corn should end up with a final plant population of about 28,000 plants on most soils with most varieties and 22,000 to 24,000 for non-irrigated corn and can vary with soil type and hybrid.

7. Nitrogen-Nitrogen applications should be split. For both irrigated and non-irrigated corn, N should be applied at 20-30 lbs/A as a starter, 30-40 $\mathrm{lbs} / \mathrm{A}$ when corn is 12-15 inches tall, and $60 \mathrm{lbs} / \mathrm{A}$ when corn is 24-30 inches tall. An additional rate of 60-80 lbs/A can be applied 2 weeks later through the irrigation system for irrigated corn. All $\mathrm{N}$ should be applied before or no later than silking and tasselling. Total application of $\mathrm{N}$ for non-irrigated corn is 120-150 lbs/A and 180-210 lbs/A for irrigated corn, depending on soil type and cropping history. Other nutrients should be applied according to soil tests at planting. Potassium may be split with $1 / 3$ applied at planting and the remainder by the time corn is 24 inches tall on sandy soils.

8. Weed control-Effective weed control is one of the many critical components of successful corn production. Weeds must be controlled early for best yields and lowest cost.
9. Insect control-Insect control on new planted corn is critical to good stands and yield. Scout for late season insect control and pay attention to stink bugs prior to silking.

10. Rotation-Good rotation is key to maintaining good yields and nematode levels should be monitored at the end of every season. See EDIS publication ENY-27 Nematode Assay Laboratory (http://edis.ifas.ufl.edu/SR001) for information on how to monitor nematode populations. 
Table 1. Short and Mid Season Irrigated Corn Variety Trial for Silage, Quincy, FL in 2003.

\begin{tabular}{|c|c|c|}
\hline Brand & Hybrid & $\begin{array}{c}\text { Silage yield } \dagger \\
---- \text { T/A---- } \\
\end{array}$ \\
\hline DeKalb & DKC69-71(RR/YGCB)* & 33.3 \\
\hline Pioneer & 32D99 & 29.1 \\
\hline NK & $1851 W$ & 26.6 \\
\hline Croplan Genetics & 827RR & 25.7 \\
\hline Pioneer & 33Ј56 & 25.0 \\
\hline Garst & $8230 \mathrm{IT}^{*}$ & 24.8 \\
\hline DeKalb & DKC67-60(RR) & 24.6 \\
\hline Croplan Genetics & $780 \mathrm{RR} / \mathrm{Bt}^{*}$ & 24.6 \\
\hline Dyna-Gro & $58 \mathrm{~K} 22$ & 24.2 \\
\hline Croplan Genetics & $895 \mathrm{Bt}^{\star}$ & 23.8 \\
\hline Southern States & SS842RR* & 23.7 \\
\hline Croplan Genetics & DS822RR* & 23.6 \\
\hline Garst & $8288^{*}$ & 23.5 \\
\hline Greenwood & $780^{*}$ & 23.5 \\
\hline Dyna-Gro & $58 K 56^{*}$ & 23.3 \\
\hline NK & N 82-N5* & 22.3 \\
\hline Croplan Genetics & DS830* & 21.5 \\
\hline \multicolumn{2}{|l|}{ Average } & 24.9 \\
\hline \multicolumn{2}{|l|}{$\operatorname{LSD}_{(0.05)}$} & 5.5 \\
\hline \multicolumn{3}{|c|}{$\begin{array}{l}\text { †Silage yields adjusted to 35\% DM. } \\
\text { *Mid-Season hybrid. }\end{array}$} \\
\hline
\end{tabular}

Table 2. Full Season Irrigated Corn Variety Trail for silage, Quincy, FL in 2003.

\begin{tabular}{|llc|}
\hline \hline Brand & Hybrid & $\begin{array}{c}\text { Silage yield }+ \\
\text {-.--T/A---- }\end{array}$ \\
\hline Pioneer & $30 \mathrm{~F} 33$ & 29.3 \\
Greenwood & 865 & 27.1 \\
Greenwood & 863 & 26.7 \\
NK & N91-R9 & 26.4 \\
Greenwood & 835 & 23.1 \\
\hline Average & & 26.5 \\
LSD & & 3.0 \\
\hline †.05) & & \\
\hline \hline
\end{tabular}


Table 3. Short Season Irrigated Corn Variety Trail for Grain, Quincy, FL in 2003.

\begin{tabular}{|c|c|c|}
\hline Brand & Hybrid & $\begin{array}{l}\text { Grain yield† } \\
----B u / A----\end{array}$ \\
\hline DeKalb & DKC67-60(RR) & 175 \\
\hline Dyna-Gro & 5518 & 169 \\
\hline Terral & TV214nRR & 169 \\
\hline Terral & TV2140RR & 166 \\
\hline Terral & TV2130 & 165 \\
\hline Dyna-Gro & $58 \mathrm{~K} 15$ & 157 \\
\hline Dyna-Gro & 5515 & 157 \\
\hline Terral & TV25B30 & 157 \\
\hline Pioneer & $31 \mathrm{G} 98$ & 156 \\
\hline NK & $1851 W$ & 155 \\
\hline Southern States & SS781CL & 154 \\
\hline Dyna-Gro & 5545 & 153 \\
\hline Vigoro & V58Y41 & 153 \\
\hline Terral & TV2160Bt & 153 \\
\hline Dyna-Gro & $58 \mathrm{~K} 22$ & 152 \\
\hline Terral & TV2160Bt & 152 \\
\hline Croplan Genetics & 691LLBt & 152 \\
\hline Croplan Genetics & 818BtRR & 151 \\
\hline Terral & TV26B23 & 150 \\
\hline Pioneer & 33M54 & 147 \\
\hline DeKalb & DKC66-80(RR) & 147 \\
\hline Terral & TV24R10 & 138 \\
\hline Terral & TV26BR10n & 137 \\
\hline Average & & 155 \\
\hline $\operatorname{LSD}_{(0.05)}$ & & NS \\
\hline
\end{tabular}

Table 4. Mid and Full Season Irrigated Corn Variety Trial for Grain, Quincy, FL in 2003

\begin{tabular}{|llc|}
\hline \hline Brand & Hybrid & $\begin{array}{c}\text { Grain yield } \dagger \\
\text {----Bu/A---- }\end{array}$ \\
\hline Pioneer & $32 \mathrm{D} 99$ & 164 \\
Greenwood & 780 & 154 \\
DeKalb & DKC69-71(RR/YGCB) & 153 \\
Greenwood & $863^{*}$ & 146 \\
Pioneer & 31G66 & 145 \\
NK & N 83-N5 & 138 \\
Croplan Genetics & DS822RR & 138 \\
NK & N91-R9* & 131 \\
Garst & 8288 & 131 \\
\hline \hline
\end{tabular}


Table 4. Mid and Full Season Irrigated Corn Variety Trial for Grain, Quincy, FL in 2003

\begin{tabular}{|c|c|c|}
\hline Brand & Hybrid & Grain yield $\dagger$ \\
\hline Southern States & SS842RR & 131 \\
\hline Vigoro & V61R36 & 129 \\
\hline Dyna-Gro & $58 \mathrm{~K} 56$ & 123 \\
\hline Garst & $8230 I T$ & 115 \\
\hline Average & & 138 \\
\hline $\operatorname{LSD}_{(0.05)}$ & & 23 \\
\hline \multicolumn{2}{|c|}{$\begin{array}{l}\text { †Grain yields adjusted to } 15.5 \% \text { moisture. } \\
\text { *Full-season hybrid. }\end{array}$} & \\
\hline
\end{tabular}

